\title{
A Study on Finance in Haulage
}

\author{
Liběna Kantnerová \\ University of South Bohemia in České Budějovice, České Budějovice, the Czech Republic
}

\begin{abstract}
A study was made on the financial statements of one Czech company which is specialized in haulage. The company is more than 20 years old, till now has been growing widely. But the size of the company now does not enable it to continue in this way and the first steps toward change have been made. It has about 300 employees and trucks, and it had big problems with solvency last year. As with other companies which have business in road transport, they are put in a big risk of bankruptcy because of the saturated and very competitive market, increasing prices of petrol and government duties such as tolls and of course are influenced by global and general economic problems in the Czech Republic. A financial analysis is an investigation that must be carried out in logical order. It comprises parts that are interlinked and should not therefore be carried out in isolation. Financial analysis constantly seeks to establish a logical sequence of criteria, as well as looking for any disruptive factor that may be a prelude to problems in the future.
\end{abstract}

Keywords: profit, financial statement, haulage, cost, analysis

According to the credit management service company_-Intrum Justitia, the percentage of written off debt (bad debt) in the Czech Republic in 2012 was $2.6 \%$ and in 2013 was $3.1 \%$. The European average was $2.7 \%$ in 2013 (about 330 billion EUR) and the average in days is about 60 days. A worse situation than in the Czech Republic is only found in Italy and Spain (more than 90 days). The average in the Czech Republic in the transport sector is 75 days ${ }^{1}$. This situation caused by crisis in 2008 has two results by Mishkin (2013) - mismanagement of financial liberalisation and globalisation and severe fiscal imbalances.

Till now, "our" company has been growing wildly, without any rules. All operations were managed by the owner. But the size of the company now does not enable it to continue in this way and the first steps toward change have been made. There are two managers helping the owner to manage all processes in the company and build a strategy and plans for the future.

One of the steps was to make a financial analysis to find - if any mistakes and sources.

According to Brealey, Myers, and Allen (2008), managers learn from experience about how to cope with routine problems. But the best managers are also able to respond to change.

Gourdin (2008) stated that road haulage offers more flexibility and versatility to the shipper than virtually any other form of transportation. This mode tends to be used for higher value/lower volume cargo than that moved by rail and can offer essentially a door-to-door service from seller to buyer. National governments can influence their transportation systems in a number of ways.

Road transport has really increased in the Czech Republic in the last 25 years (Kantnerová, 2011). See data from Eurostat below (see Table 1).

Corresponding author: Liběna Kantnerová, Ph.D., senior lecturer, University of South Bohemia in České Budějovice, the Czech Republic; research fields: banking, finance, and financial literacy. E-mail: kantner@ef.jcu.cz.

${ }^{1}$ Retrieved from http://www.mpo.cz/dokument141226.htm. 
Table 1

Modal Split of Freight Transport (\% of Total Inland Freight in Tonne-Kms)

\begin{tabular}{llllllllll}
\hline & 2005 & 2006 & 2007 & 2008 & 2009 & 2010 & 2011 & 2012 \\
\hline EU (28 countries) & 17.7 & 18.0 & 17.9 & 17.9 & 16.5 & 17.1 & 18.3 & 18.2 \\
The Czech Republic & 25.5 & 21.8 & 25.3 & 23.3 & 22.1 & 21.0 & 20.7 & 21.8 & \\
\hline
\end{tabular}

Notes. EU-European Union; Source: see the website ${ }^{2}$; the author's own work.

On pages ${ }^{3}$, we can find data about employees in road transport. The Czech Republic has work for about 50,000 people in this sector (data from last five years are not available). The biggest employers in this sector are Spain and Italy. From all this data, it follows the fact of the big importance of this sector for the economy of each country.

Because of the key role played by transportation in a nation's economy, governments have historically taken a great interest in how it is accomplished. For some nations, this involvement has taken the form of outright national ownership of transport resources such as airlines, steamship lines, and railways; other countries have chosen to rely on the private sector to provide these services. However, regardless of location, transportation services have almost always taken place within a complex framework of laws and regulations seemingly intended to protect the industries themselves at the expense of efficient resource utilization and customer service.

Road haulage offers more flexibility and versatility to the shipper than virtually any other form of transportation. This mode tends to be used for higher value/lower volume cargo than that moved by rail and can offer essentially door-to-door service from seller to buyer. However, the global logistics manager will find that trucking can vary dramatically from country to country. One of the possibilities of how to solve problems of the situation of the competitive market is Porter's theory of competitive advantage and the value chain. Yet, in general, logistics has remained a rather underappreciated part of many firms. However, dramatic changes in the international business environment in recent years have led to an increased role for logistics in firm operating globally.

Due to emerging problems and current global recession, current procedures are not sufficient for successful management. Therefore, entrepreneurs and managers need to extend existing methods with new ones, which will lead to better management. This can be achieved by introducing new concepts and technologies that may help to achieve the main objectives, mainly to ensure profitability and liquidity of the company (Kantnerová, 2011).

According to Fabozzi and Peterson (2002), the leasing of an asset is often an alternative to purchasing it. But there is a difference between leasing and buying. A firm buying an asset can finance it using debt, activity, or some of both.

The owner and managers analyse the situation of the market and within the company, and there are lots of opportunities to find solutions to problems. One of them is financial analysis.

According to Vernimmen, Quiry, Dalocchio, Le Fur, and Salvi (2011), financial analysis is a tool used by existing and potential shareholders of a company, as well as lenders or rating agencies. For shareholders, financial analysis assesses whether the company is able to create value. It usually involves an analysis of the value of the share and ends with the formulation of a buy or a sell recommendation on the share. For lenders, financial analysis assesses the solvency and liquidity of a company, i.e., its ability to honour its commitments

\footnotetext{
${ }^{2}$ Retrieved from http://epp.eurostat.ec.europa.eu/tgm/table.do?tab=table\&init=1\&language=en \&pcode=tsdtr220\&plugin=1.

${ }_{3}^{3}$ Retrieved from http://epp.eurostat.ec.europa.eu/portal/page/portal/transport/data/database.
} 
and repay its debts on time.

A financial analysis is an investigation that must be carried out in logical order. It comprises parts that are interlinked and should not therefore be carried out in isolation. Financial analysis constantly seeks to establish a logical sequence of criteria, as well as looking for any disruptive factor that may be a prelude to problems in the future. Fridson and Alvarez (2011) state that the primary goal in financial reporting is the dissemination of financial statements that accurately measure the profitability and financial condition of a company.

The goal of analysing an income statement is essentially to determine whether the story it tells is good, bad, or indifferent. To accomplish this objective, the analyst draws a few initial conclusions, then puts the income statement into context by comparing it with income statement of earlier periods, as well as statements of other companies. The problem is value, which accountants wrestle with and which has also historically plagued philosophers, economists, tax assessors, and the judiciary.

Business enterprises typically go through phases of development that are in many respects analogous to a human being's stages of life. Just as children are susceptible to illnesses different from those that afflict the elderly, the risks of investing in young companies are different from the risks inherent in mature companies. Accordingly, it is helpful to understand which part of the life cycle a company is in and which financial pitfalls it is therefore most likely to face. See below for better understanding the Figure 1 with the description of the life cycle a company.

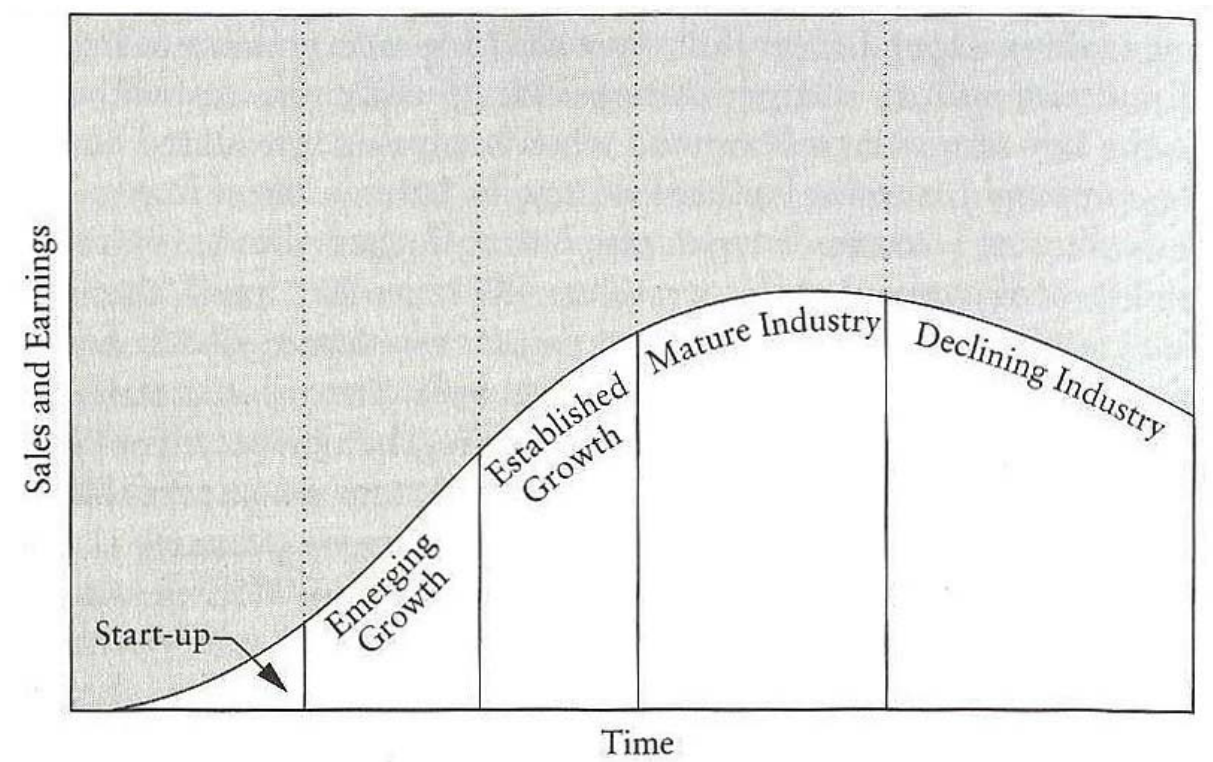

Figure 1. The life cycle of any company. Source: Fridson and Alvarez (2011).

Profit holds an exalted place in the business world and in economics. The necessity of producing profits imposes order and discipline on business organisations. It fosters cost-reducing innovations, which in turn promote the efficient use of scare resources. The profit motive also encourages savings and risk-taking, two indispensable elements of economics development. Finally, profitability is a yardstick by which businesspeople can measure their achievements and justify their claims to compensation.

In the conditions of the market economy, all enterprises not only try to survive, but also maximise theirs results. We can determine a healthy enterprise as one which does not have any problems with its liquidity and is profitable too. 


\section{Results}

\section{Conditions of the Czech Market}

The following part describes the conditions of the Czech market as the environment of the company business. The next table shows the values of exchange of CZK/EUR, which is necessary to do in the situation of paying petrol and tolls abroad (see Table 2).

Table 2

The Exchange Rate of EUR in the Czech Republic (in CZK)

\begin{tabular}{lllll}
\hline Year & January-March & April-June & July-September & October-December \\
\hline 1999 & 37,156 & 37,607 & 36,428 & 36,340 \\
2000 & 35,771 & 36,289 & 35,459 & 34,911 \\
2001 & 34,798 & 34,298 & 34,024 & 33,202 \\
2002 & 31,756 & 30,405 & 30,247 & 30,853 \\
2003 & 31,628 & 31,477 & 32,167 & 32,089 \\
2004 & 32,859 & 32,027 & 31,587 & 31,126 \\
2005 & 30,014 & 30,126 & 29,677 & 29,298 \\
2006 & 28,600 & 28,384 & 28,330 & 28,045 \\
2007 & 28,037 & 28,266 & 27,923 & 26,829 \\
2008 & 25,562 & 24,826 & 24,092 & 25,342 \\
2009 & 27,599 & 26,677 & 25,598 & 25,915 \\
2010 & 25,868 & 25,589 & 24,913 & 24,786 \\
2011 & 24,375 & 24,321 & 24,388 & 25,279 \\
2012 & 25,083 & 25,261 & 25,065 & 25,167 \\
2013 & 25,568 & 25,831 & 25,852 & 26,657 \\
\hline
\end{tabular}

Note. Source: see the website 4 .

The "price" of EUR has decreased from year to year, but the last period is under the influence of the intervention of the Czech central bank and for 2014 is growing again. The value of it did not fall under 27.40 CZK/EUR. The results of this intervention are not known yet (only from some research is seen a mostly negative response of people in the business). In contrast, prices of petrol in the domestic market are growing from year to year and this situation caused problems for transport companies, the tables below are for the explanation of the situation in searched enterprise (see Table 3 to Table 7).

The situation is caused not only by the prices in the international markets, but because of the Czech Government's duty policy, too. There is space to help in this sector of the economy, because some countries in Europe do not have such high duties on petrol, and for a Czech transport company, it is an economical decision to buy the petrol in some of these other countries. What this in the end means is that our government has probably lost out in this sector.

\section{An Analysed Company and Some of Its Results Are Described Below}

The next table highlights the situation of the cost of salaries (see Table 3).

During the last 10 years, the average salary is two times higher. The level of salary is given by the competition in the sector, not chosen by the financial possibility of the enterprise. The average salary in the

\footnotetext{
${ }^{4}$ Retrieved from http://www.cnb.cz/cs/financni_trhy/devizovy_trh/kurzy_devizoveho_trhu/grafy_form_js.jsp, own work.
} 
Czech Republic was 25,942 CZK up to January 1, 2014 (approximately 943 EUR). For the better comparison of the situation in different countries, see the next figure which highlights the situation in the price of petrol on the Czech Republic (see Figure 2).

Table 3

Salaries of One Member of Staff in the Company

\begin{tabular}{ll}
\hline Years & Average costs of one worker (CZK/year) \\
\hline 2004 & 93,412 \\
2005 & 161,298 \\
2006 & 117,726 \\
2007 & 195,314 \\
2008 & 216,491 \\
2009 & 198,664 \\
2010 & 196,423 \\
2011 & 205,146 \\
2012 & 213,852 \\
2013 & 223,576 \\
\hline
\end{tabular}

Note. Source: the author's own work.

Table 4

Domestic Turnover (in Thousands of CZK)

\begin{tabular}{ll}
\hline Years & Turnover \\
\hline 2004 & 213,894 \\
2005 & 279,451 \\
2006 & 455,824 \\
2007 & 725,654 \\
2008 & 685,720 \\
2009 & 547,482 \\
2010 & 534,560 \\
2011 & 520,054 \\
2012 & 539,668 \\
\hline
\end{tabular}

Note. Source: the author's own work.

Table 5

Turnover From International Transport (in Thousands of CZK)

\begin{tabular}{ll}
\hline Years & Turnover \\
\hline 2004 & 153,347 \\
2005 & 180,634 \\
2006 & 201,535 \\
2007 & 216,988 \\
2008 & 250,291 \\
2009 & 238,644 \\
2011 & 185,769 \\
2012 & 175,574 \\
\hline
\end{tabular}

Notes. Data from 2010 are not available. Source: the author's own work. 
Table 6

Number of Trucks and Installments in the Leasing of Them

\begin{tabular}{lll}
\hline Years & Number of trucks & Annual installment of leasing (thousand of CZK) \\
\hline 2004 & 118 & 1,876 \\
2005 & 139 & 6,448 \\
2006 & 236 & 48,213 \\
2007 & 338 & 69,736 \\
2008 & 378 & 193,612 \\
2009 & 350 & 89,750 \\
2010 & 368 & 124,806 \\
2011 & 306 & 87,000 \\
2012 & 320 & 123,617 \\
2013 & 344 & 138,014 \\
\hline
\end{tabular}

Note. Source: the author's own work.

Table 7

Debts From Sales (in Thousands of CZK)

\begin{tabular}{llllllll}
\hline Years & Up to 30 days & Up to 60 days & Up to 90 days & Up to 180 days & Up to 365 days & Over 365 days & Total \\
\hline 2006 & 16,300 & 8,600 & 10,625 & 12,860 & 6,587 & 0 & 54,972 \\
2007 & 21,593 & 4,282 & 811 & 2,472 & 860 & 3,724 & 33,742 \\
2008 & 35,468 & 12,990 & 3,218 & 2,984 & 247 & 1,058 & 55,965 \\
2009 & 35,548 & 3,200 & 20,748 & 1,004 & 3,011 & 4,073 & 67,584 \\
2010 & 40,719 & 11,365 & 412 & 157 & 405 & 9,406 & 62,464 \\
2011 & 19,900 & 6,950 & 6,251 & 6,801 & 40,069 & 5,584 & 85,555 \\
2012 & 24,966 & 10,296 & 7,336 & 33,767 & 17,224 & 6,218 & 99,807 \\
\hline
\end{tabular}

Note. Source: the author's own work.

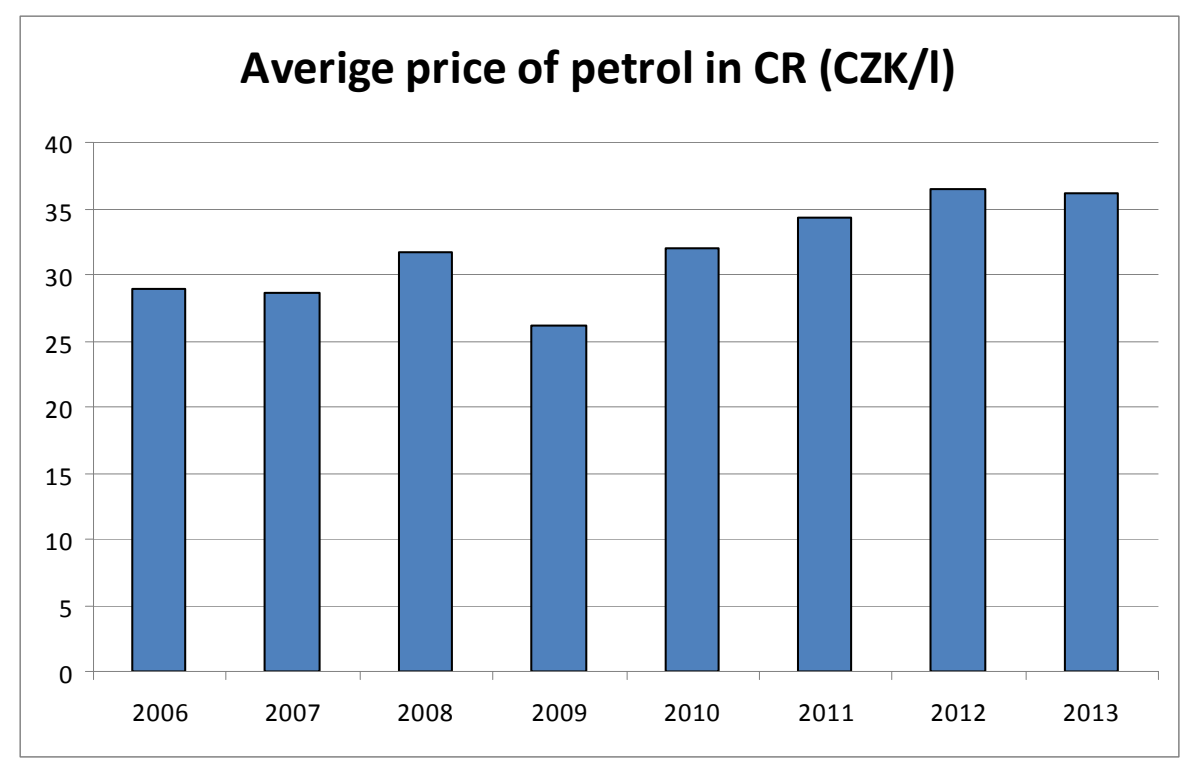

Figure 2. The average price of petrol. Sources: see the website ${ }^{5}$ and the author's own work.

\footnotetext{
${ }^{5}$ Retrieved from http://www.mdcr.cz/cs/Statistika_dopravy/default.htm.
} 
The break in the positive growth in sales was in the economic crisis years. The level of growth in the last four years has been very slow. We can see the same trend in the following table, describing the situation in international transport (see Table 5).

The next table highlights the cost of trucks - the situation in the numbers of them and installments in the leasing of them.

The general situation in the market is described in the following table (see Table 7). There the situation of the debts from sales is shown, which was the worst in the years of the crisis. The improvement of the situation in the last two years was made in co-operation with a specialised company, but the situation in the market does not allow for a big improvement.

\section{Financial Analysis of the Company}

In the financial analysis, lots of aspects play an important role. Amongst very important and basic criteria belong rentability and liquidity, which will be the main focus of this paper. Because of limited sources, only some of them were chosen and the calculation was made by Czech authors P. Růčková (2010) and J. Sedláček (2009). At the end of this section, a comparison was made with data from some other transport company (with only 55 employees and 35 trucks, afterwards called the comparison company) and with the average data for the whole sector, all for 2012.

The first group regarding rentability compares the profit and level of resources of a company, which were used to reach it.

ROA (return on assets) $=$ EBIT (earnings before interest and taxes)/assets

The results of the company reached in the last years are shown in the next figure (see Figure 3).

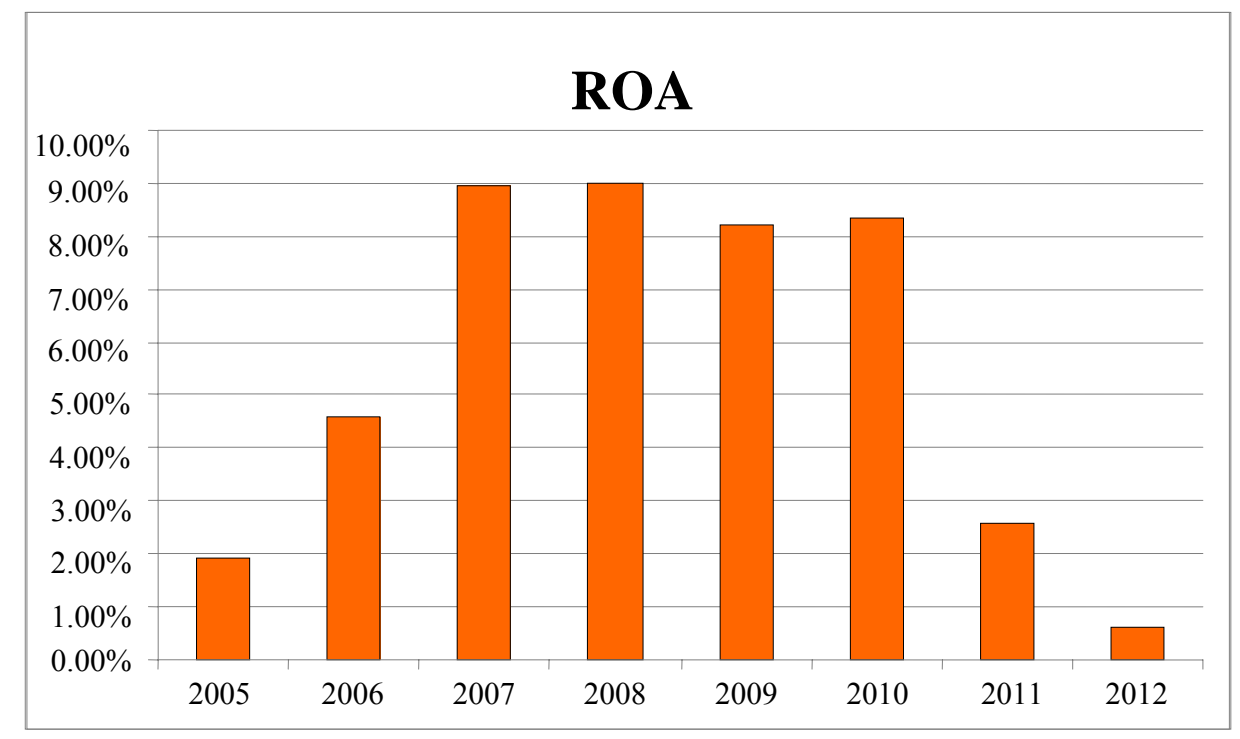

Figure 3. ROA. Source: the author's own work.

This figure shows the decline of the production force of the company after the crisis in 2008. The return on equity (ROE) measures the net income and the shareholders equity. According to Vernimmen et al. (2011), average values in different sectors inside of the European territory were between $13 \%$ and $25 \%$ in 2010 . Unfortunately, this numbers does not include the transport sector. This criterion highlights the situation of the profitability on own investment, which should be higher than the profitability of governments bonds, and as is 
shown in Figure 4-worked well. 2012 was not so successful and the situation in the next years shows if necessary, the need to change may be the strategy or the way of investment.

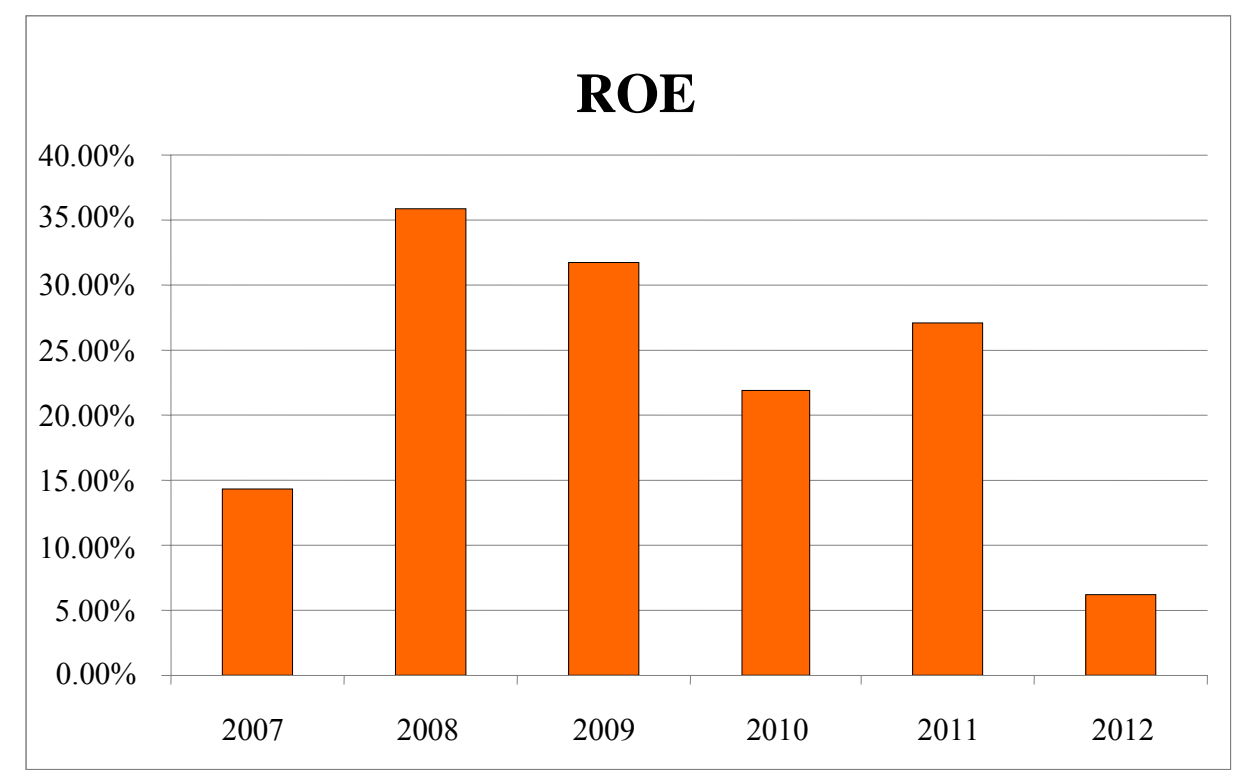

Figure 4. ROE. Source: the author's own work.

The second group of criteria is the ability of a company to pay its liabilities - the name of this is liquidity. Analysing liquidity means analysing the risk some company will have to "borrow" money to pay some obligation. For each maturity, it is necessary to compare the company's cash needs with the resources it will have at its disposal. Generally, a balance sheet is liquid when, for each maturity, there are more assets that can be converted into cash (inventories sold, receivables paid, securities, etc.) than there are liabilities due.

The first one screened is quick ratio. It is the same as the current ratio excluded from the calculation inventory.

The progress of this criterion is shown in the following figure (see Figure 5).

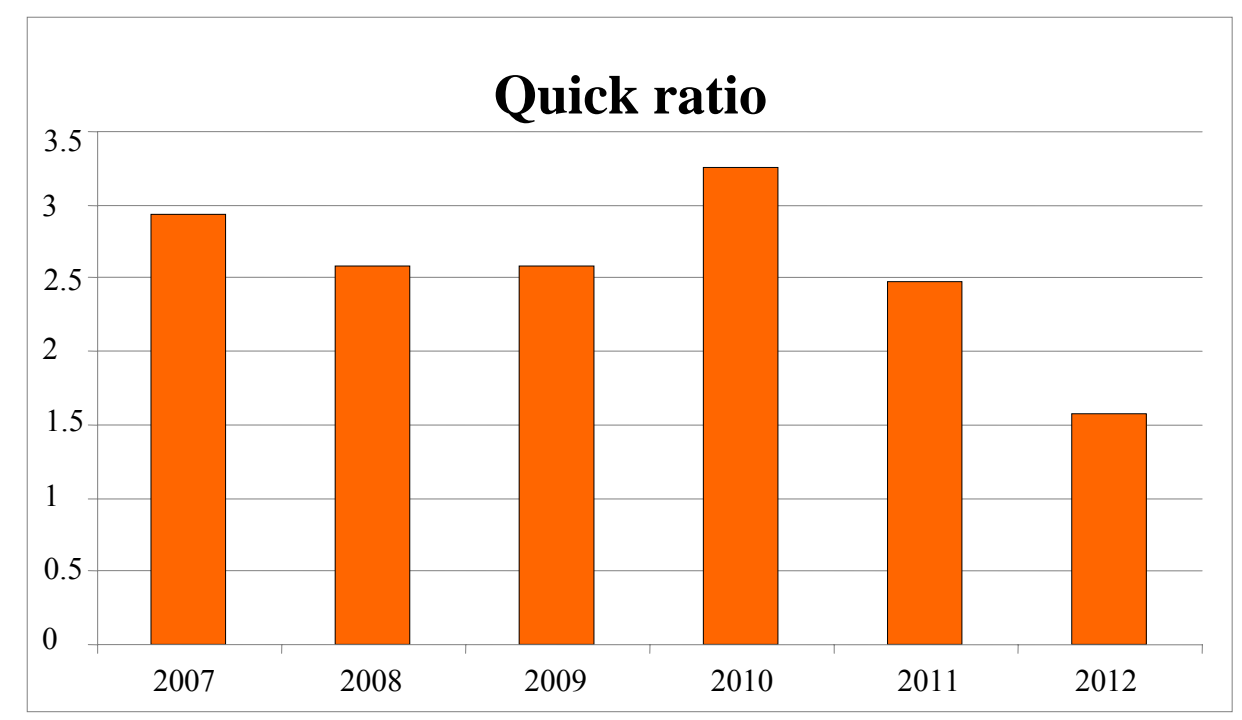

Figure 5. Quick ratio. Source: the author's own work. 
In this criterion, the situation is better from year to year and the productivity of the inventory is improving.

The cash ratio measures the proportion of cash and cash equivalents and current liabilities (cash and cash equivalents/current liabilities). This criterion shows how many times the short liabilities are covered by short assets. The quick ratio is described by the covering of liabilities only by cash.

The cash ratio is the third level of liquidity and shows how many times short assets are covered by short debts. Unfortunately, it does not show anything about the structure and duality of the assets. A good result is between 1.5 and 2.5 (see Figure 6).

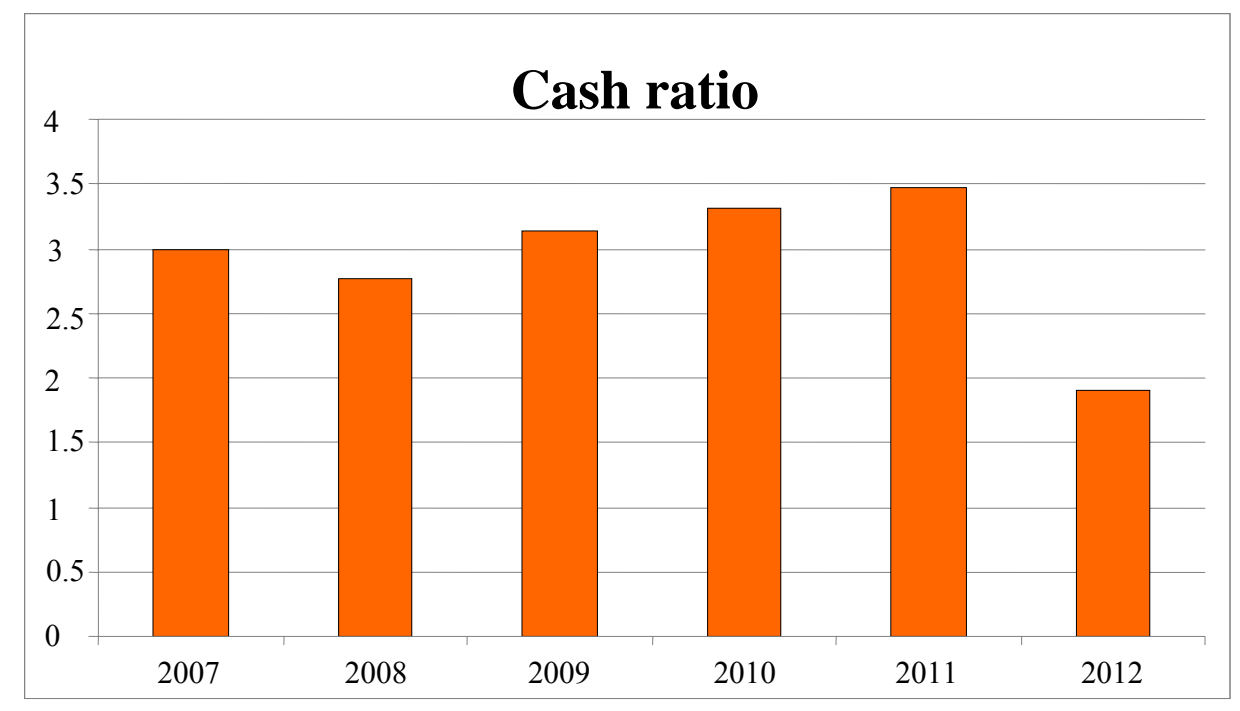

Figure 6. Cash ratio. Source: the author's own work.

From this figure, the situation in the described enterprise looks in good proportion. A small warning is the fall in 2012 and it is necessary to screen the situation in the next years. If the value decreases again, the result will be lower than optimum and liquidity will be a very important problem.

The third group of criteria — returns on revenue and costs—checks out the returns and profits on the two most screened categories in any company.

Return on revenue measures the performance of an enterprise, its ability to reach profit at the given level of sales, what it means, and how much profit is made from one Czech crown of income. In this calculation, net profit is used, after tax and other duties. Thus, the result is the profit margin.

Return on revenue $=$ profit/sales

The next figure highlights the situation in the development of this criterion (see Figure 7). This criterion demonstrates a permanent decrease with the signal of a slow increase in 2012. Optimal value is different in different sectors. It is hard to say if the situation is optimal. But the development till the year 2012 is negative. The decrease indicates the permanent decrease of the right power using incomes from sales. Development will necessarily follow. Hopefully, the value of it in 2012 is a signal of an improvement of the situation.

The rentability on costs (ROC) shows the previous criterion more specifically. Generally, smaller values are better, because this indicates better results in business.

$$
\text { ROC }=1-\text { profit/sales }
$$

We can see the same development as with the previous criterion: the value oscillates from 0.96 to 0.99 in this enterprise. 


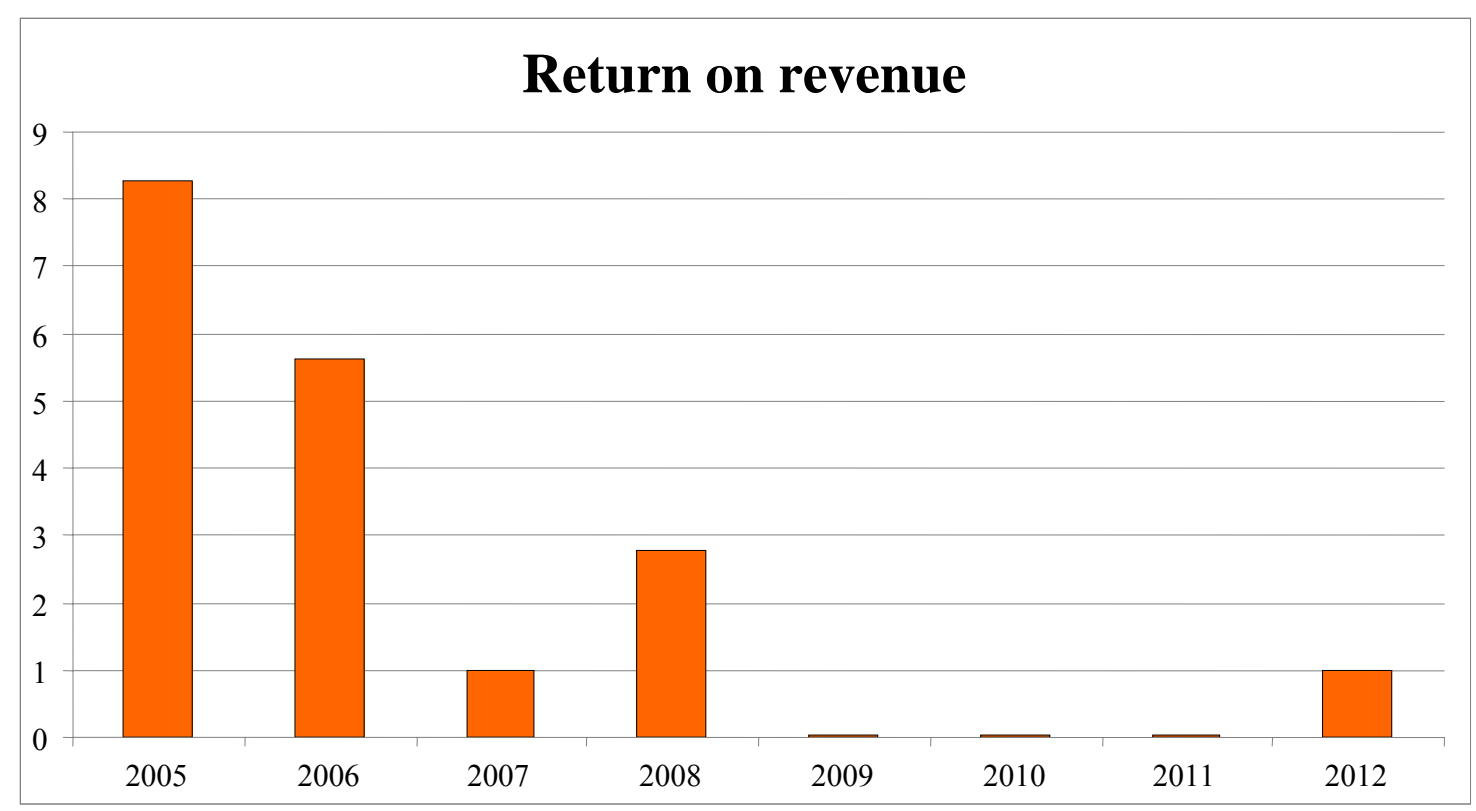

Figure 7. Return on revenue. Source: the author's own work.

The following table compares some financial critieria among the analysed company, the compared company, and the average of the sector in 2012 (see Table 8).

Table 8

The Comparison of Different Results

\begin{tabular}{llll}
\hline Criterion & Analysed company & Compared company & Average of the sector \\
\hline ROA & $0.63 \%$ & $1.3 \%$ & $3.8 \%$ \\
ROE & $6.17 \%$ & $2.5 \%$ & $4.1 \%$ \\
Costs & 0.99998 & 0.99621 & 0.95800 \\
Total assessment turnover ratio & 0.37 & 2.75 & 0.62 \\
Average collection period & 76 days & 62 days & 75 days \\
Payables turnover ratio & 44 days & 32 days & 84 days \\
Debt ratio & $72 \%$ & $58 \%$ & $35 \%$ \\
Current ratio & 1.091 & 2.015 & 1.551 \\
\hline
\end{tabular}

Note. Sources: see the website ${ }^{6}$; the author's own work.

According to Intrum Justitia, the European average for the collection period is about 60 days. The worst situation is in Italy and Spain (where it is more than 90 days); the best is in Scandinavian countries.

\section{Conclusions}

In the conditions of the market economy, all enterprises try not only to survive, but to maximalise theirs results also. We can determine such a healthy enterprise, which does not have any problems with its liquidity and is profitable too.

The analysed company has big problems with its liquidity and uses lots of external sources (credits). The analysed criteria look to be in the range of business in 2012 or are lower as is shown in the tables and figures.

\footnotetext{
${ }^{6}$ Retrieved from http://www.mpo.cz/dokument141226.html.
} 
The biggest problem for the company looks to be the debts of their clients. This makes the cash flow insufficient and the company needs external sources of finance for their survival, development, and debts. The company should arrange steps to avoid such a situation.

At first, the company needs to do some changes in the organisation of work and management. It is necessary to do a SWOT (Superiority Weakness Opportunity Threats) analysis too, to find some possibilities of better management. Written rules concerning debts should be made and kept. A special department or at least some staff should be obliged to take care of debts and co-operate with the business department. The building up of a control department looks to be an optimal way of how to improve the situation. This department can take care of, not only debts, but some other situations such as lost small items (e.g., spare parts, petrol), the better organisation of stock, etc.

The second way can be changed in business. In a SWOT analysis, the company can find some other profitable service connected with haulage and offer it to their customers, e.g., renting space for advertising, machinery maintenance, some administrative service connected with transport, etc. As proof of the benefit of changes in business is the better situation of the second, comparison company. It has, e.g., in addition to haulage, personnel transport also (five buses) for the needs of a travel agency.

A third solution can be the connection with some other companies in a chain. It is a good solution for ordering spare parts, in the centralisation of ordering transport, etc.

\section{References}

Brealey, R. A., Myers, S. C., \& Allen, F. (2008). Principles of corporate finance. Singapore: Mc G. Hill.

Fabozzi, F. J., \& Peterson, P. P. (2002). Capital budgeting. Danvers: Wiley.

Fridson, M., \& Alvarez, F. (2011). Financial statement analysis. New York: J. Wiley.

Gourdin, K. N. (2008). Global logistics management. Victoria: Blackwell Publishing.

Kantnerová, L. (2011). Možnosti uplatnění logistického controllingu v malých a středně velkých podnicích (The possibility of using logistiv controlling in small and middle sized companies). Dissertation thesis. The University of South Bohemia, České Budějovice.

Knápková, A., \& Pavelková, D. (2010). Finančni analýza (The financial analysis). Praha: Grada Publishing.

Mishkin, F. S. (2013). The economics of money, banking, and financial markets. UK: Pearson Education Ltd.

Novák, R. (2003). Mezinárodní kamionová doprava Plus (The advantages of international transport). Praha: ASPI.

Novák, R., Pernica, P., Svoboda, V., \& Zelený, L. (2005). Nákladní doprava a zasilatelství (The haulage and forwarding). Praha: ASPI.

Růčková, P. (2010). Finančni analýza (The financial analysis). Praha: Grada Publishing.

Sedláček, J. (2009). Finanční analýza podniku (The financial analysis of a company). Brno: Computer Press.

Vernimmen, P., Quiry, P., Dalocchio, M., Le Fur, Y., \& Salvi, A. (2011). Corporate finance, theory and practice. West Sussex: J. Wiley Ltd. 